\title{
Identification and characterization of a novel cell-penetrating peptide of 30Kc19 protein derived from Bombyx mori
}

\author{
Hee Ho Park ${ }^{\mathrm{a}}$, Youngsoo Sohn ${ }^{\mathrm{b}}$, Ji Woo Yeo ${ }^{\mathrm{a}}$, Ju Hyun Park ${ }^{\mathrm{a}}$, Hong Jai Lee ${ }^{\mathrm{a}}$, Jina Ryu ${ }^{\mathrm{b}}$, \\ Won Jong Rhee ${ }^{\mathrm{c}}$, Tai Hyun Park ${ }^{\mathrm{a}, \mathrm{b}, \mathrm{d}, *}$ \\ a The School of Chemical and Biological Engineering, Seoul National University, Seoul 151-744, Republic of Korea \\ ${ }^{\mathrm{b}}$ Interdisciplinary Program for Bioengineering, Seoul National University, Seoul 151-744, Republic of Korea \\ ${ }^{\mathrm{c}}$ Division of Bioengineering, Incheon National University, Incheon 406-772, Republic of Korea \\ d Advanced Institutes of Convergence Technology, Suwon 443-270, Republic of Korea
}

\section{A R T I C L E I N F O}

\section{Article history:}

Received 21 February 2014

Received in revised form 24 April 2014

Accepted 13 May 2014

Available online 22 May 2014

\section{Keywords:}

30Kc19 protein

Cell-penetrating peptide (CPP)

30Kc1945-57 (Pep-c19)

Protein delivery

In vivo penetration

\begin{abstract}
A B S T R A C T
Cell-penetrating peptides (CPPs) or protein transduction domains (PTDs) have attracted increasing attention due to their high potential to deliver various, otherwise impermeable, bioactive agents, such as drugs and proteins across cell membranes. A number of CPPs have been discovered since then. Recently, 30Kc19 protein has attracted attention because it was the first cell-penetrating protein that has been found in insect hemolymph. Here, we report a cell-penetrating peptide derived from 30Kc19 protein, VVNKLIRNNKMNC, which efficiently penetrates cells when supplemented to medium for mammalian cell culture. Moreover, like other CPPs, this "Pep-c19” also efficiently delivered cell-impermeable cargo proteins, such as green fluorescent protein (GFP) into cells. In addition to the in vitro system, Pep-c19 exhibited the cell-penetrating property in vivo. When Pep-c19 was intraperitoneally injected into mice, Pep-c19 successfully delivered cargo proteins into various organ tissues with higher efficiency than the 30 Kc19 protein itself, and without toxicity. Our data demonstrates that Pep-c19 has a great potential as a cell-penetrating peptide that can be used as a therapeutic tool to efficiently deliver different cell-impermeable cargo molecules into the tissues of various organs.
\end{abstract}

(c) 2014 Elsevier Ltd. All rights reserved.

\section{Introduction}

In the past two decades a new class of peptides has gained increasing attention. These so-called "cell-penetrating peptides" are usually less than 30 amino acids in length, and are comprised of cationic and/or hydrophobic residues [1,2]. These cell-penetrating peptides have the ability to penetrate rapidly into living mammalian cells, and hence, can be used to deliver various functional cargo molecules, such as proteins [3-6], small molecules

Abbreviations: CPP, cell-penetrating peptide; PTD, protein transduction domain; TAT, trans-activator of transcription; GFP, green fluorescent protein; SDS, sodium dodecyl sulfate; PAGE, polyacryl amide gel electrophoresis; HRP, horseradish peroxidase; CLC, Cake-Loving Company; EMBOSS, The European Molecular Biology Open Software Suite; LOOP, Learning, Observing and Outputting Protein Patterns; DMEM, Dulbecco's modified Eagle medium; BUN, blood urea nitrogen; ALT, aspartate aminotransferase; AST, alanine aminotransferase.

* Corresponding author at: The School of Chemical and Biological Engineering, Seoul National University, Seoul 151-744, Republic of Korea. Tel.: +82 2880 8020; fax: +8228759348 .

E-mail address: thpark@snu.ac.kr (T.H. Park).
[7-9], nucleic acids [10-12], antibodies [13,14], and nanoparticles [15-18]. The exact mechanism responsible for the uptake of CPPs and their cargoes has not yet been fully established; however, a number of studies are now emphasizing the role of endocytosis [19-21], and in particular macropinocytosis [22-24], direct penetration [25,26], and inverted micelle [27-29]. Proteins and peptides have been found to move across the cell membrane since the initial discovery of TAT CPP derived from HIV-1 virus in 1988 [30,31], penetratin CPP derived from Antennapedia of Drosophila melanogaster in 1994 [32,33], and VP22 CPP derived from herpes simplex virus in 1997 [34,35]. Although several CPPs have been identified, it remains important to find new peptides that are efficient vehicles for the delivery of cargos, and with low toxicity because some have toxic effects on membranes of cells and organelles, including toxic effects resulting from the specific interaction of CPPs with cell components [2].

$30 \mathrm{Kc} 19$ protein is a member of the $30 \mathrm{~K}$ protein family, a similar structured protein found in hemolymph of Bombyx mori [36]. These proteins have molecular weights of around $30 \mathrm{kDa}$, and $30 \mathrm{Kc} 19$ protein is the most abundant among $30 \mathrm{~K}$ proteins (30Kc6, 30Kc12, $30 \mathrm{Kc} 19,30 \mathrm{Kc} 21$ and 30Kc23) in the hemolymph [37]. During the 
5th instar larva to early pupa stage, these $30 \mathrm{~K}$ proteins are synthesized in fat body cells and accumulate in the hemolymph $[38,39]$. They are then transferred from the hemolymph to fat body cells during metamorphosis from larva to pupa, and are deposited there until later use $[40,41]$. Although the biological functions of the $30 \mathrm{~K}$ proteins in silkworms have not been fully determined, several studies have recently examined their functional properties for 30Kc6 and 30Kc19 [41,42]. In previous studies, we have demonstrated that gene expression or addition of recombinant $30 \mathrm{~K}$ proteins to culture medium produced from Escherichia coli (E. coli) exhibited anti-apoptotic effects in various cells [43-55]. 30K proteins also enhanced productions of recombinant erythropoietin, interferon$\beta$, and monoclonal antibody, as well as increasing glycosylation, cell growth, and viability in various cells, and also had enzymestabilizing effects [56-62]. A recent study has shown that 30Kc19 protein has a cell-penetrating property when supplemented to the culture medium [63]. Therefore, 30Kc19 protein is a very unique multi-functional protein, and can be applied for the delivery of therapeutic proteins, including enzymes, as it can penetrate cell membrane as well as stabilizing cargo proteins. However, for the practical use in delivery of cell-impermeable cargo molecules, it is necessary to find a cell-penetrating domain like other cell-penetrating proteins that can efficiently deliver cargo molecules into cells.

Here, we report a cell-penetrating peptide of 30Kc19 protein (Pep-c19), originating from the silkworm. Through computational analyses, we managed to identify a peptide that has a cellpenetrating property and investigated the efficiency and toxicity of this "Pep-c19" in comparison with its original protein, 30Kc19, both in vitro and in vivo.

\section{Materials and methods}

\subsection{Materials}

Total RNA was isolated from Bombyx mori silkworm at the fifth-instar larval stage using RNeasy (Qiagen, Valencia, CA, USA). The 30Kc19 cDNA was obtained by RT-PCR, and the 30Kc19 gene was then amplified using PCR. This DNA fragment was then inserted into a pET-23a expression vector (Novagen, Madison, WI, USA) with a $\mathrm{T} 7 \mathrm{tag}$ at the $\mathrm{N}$-terminus and a 6 -His tag at $\mathrm{C}$-terminus. Then, truncated forms of 30Kc19; 30Kc19 1 120 and 30Kc19 $121-239$ were also constructed. For GFP-30Kc19, ORFs of GFP were cloned from pCMV-AC-GFP vector (Origene, Rockville, MD, USA) to $\mathrm{N}$-terminal of $30 \mathrm{Kc} 19$ in pET-23a vector. The GFP-30Kc19 contained two amino acids (Glu, Phe) derived from the EcoR I sequence (GAATTC) between GFP and 30Kc19. GFP-Pep-c19; $30 \mathrm{Kc}_{19} 9_{42-57}$ sequence at the C-terminus of GFP was constructed to pET-23a vector. Constructed vectors were then transformed to E. coli BL21 (DE3, Novagen) and cells were grown in LB-ampicillin medium at $37^{\circ} \mathrm{C}$. Isopropyl 1-thio$\beta$-D-galactopyranoside (IPTG, $1 \mathrm{mM}$ ) was used for the induction. E. coli were then further incubated at $37^{\circ} \mathrm{C}$ for the production of protein, except for GFP-30Kc19, for which $30^{\circ} \mathrm{C}$ was selected as the induction temperature. After centrifugation, cells were harvested and disrupted by sonication. The purified proteins, including the $30 \mathrm{Kc} 19$, were then obtained as described previously [64]. Briefly, following the lysis of cells, all recombinant proteins were purified from the supernatant using a HisTrap HP column (GE Healthcare, Uppsala, Sweden) and was dialyzed against $20 \mathrm{mM}$ Tris-HCl buffer ( $\mathrm{pH}$ 8.0) using HiTrap Desalting (GE Healthcare) to eliminate the lipopolysaccharide (LPS) endotoxins. The purity was higher than $90 \%$ (data not shown), and was then stored at $-70^{\circ} \mathrm{C}$ until use. The quantitative analysis of each protein was performed using a Micro BCA kit (Thermo Scientific Inc., Rockford, IL, USA). N-terminal FITC-linked CPP candidates and Pep-c19 with purity of $90 \%$ were ordered from Peptron (Daejeon, Korea), and were diluted and stored at $-70^{\circ} \mathrm{C}$ until use.

\subsection{Cell culture}

HEK 293 and HeLa cells were maintained in a humidified atmosphere of 5\% $\mathrm{CO}_{2}$ at $37^{\circ} \mathrm{C}$ in DMEM (Gibco, Invitrogen, Carlsbad, CA, USA), supplemented with $10 \%(\mathrm{w} / \mathrm{v})$ fetal bovine serum (FBS, Gibco) and $1 \%(\mathrm{v} / \mathrm{v})$ penicillin streptomycin (PS, Gibco). For the $4{ }^{\circ} \mathrm{C}$ experiment, cells were pre-incubated at $4{ }^{\circ} \mathrm{C}$ for $1 \mathrm{~h}$ before proteins were added. After the addition of proteins to the culture medium, cells were incubated at either $37^{\circ} \mathrm{C}$ or $4{ }^{\circ} \mathrm{C}$ for $4 \mathrm{~h}$, unless otherwise indicated.

\subsection{Immunoblot analysis}

HEK 293 cells were treated with trypsin-EDTA (Sigma-Aldrich, St. Louis, MO, USA) and then washed with PBS three times for strict distinction between intracellular and membrane-bound proteins. Cell extracts were collected with RIPA buffer (50 mM Tris- $\mathrm{HCl}$ (pH 7.4), $150 \mathrm{mM} \mathrm{NaCl}, 1 \%$ Triton X-100, 0.1\% SDS, proteases inhibitor cocktail) at $4{ }^{\circ} \mathrm{C}$ for $1 \mathrm{~h}$ followed by centrifugation. Each cell extract containing an equal amount of total protein was resolved by PAGE and examined by immunoblot analysis. For preparation of the anti-30Kc19 rabbit antibody, 30Kc19 was first purified from the silkworm hemolymph using a two-step chromatography purification method (size exclusion, ion exchange). Anti-30Kc19 polyclonal rabbit antibody was produced by immunizing a rabbit with the purified 30Kc19 protein, which was subsequently purified by Protein G chromatography (AbFrontier, Seoul, Korea). 30Kc19 was detected using this anti-30Kc19 antibody, followed by HRP-conjugated anti-rabbit antibody (Invitrogen).

\subsection{Computational analysis}

For the identification and selection of probable CPP candidates within the 30Kc19 protein, computational analyses were performed for helix motif region, positive amino acid region, hydrophobic amino acid region, and relative surface accessibility region of $30 \mathrm{Kc} 19$ protein. Whole amino acid sequence from 1-239 of the $30 \mathrm{Kc} 19$ protein was put in for the following analyses. For the helix and hydrophobic amino acid analyses, CLC protein workbench program was used (Insilicogen, Suwon, Korea). For the amino acid charge and surface accessibility analyses, EMBOSS and LOOPP programs (Cornell University, Ithaca, NY, USA) were used, respectively.

\subsection{Quantitative internalization analysis of Pep-c19}

Internalization of FITC-linked Pep-c19 and GFP-Pep-c19 protein was measured by fluorescence intensity using a microplate reader (Tecan GENios Pro, Tecan, Durham, NC, USA). HeLa cells were seeded on 96-well plate (Nunc Lab-Tek, Thermo Scientific) and incubated overnight. FITC-linked peptides or protein were added to the culture medium and were incubated in $37^{\circ} \mathrm{C}$ in humidified atmosphere of $5 \% \mathrm{CO}_{2}$. Unless indicated otherwise, after incubation, cells were washed vigorously three times with PBS to minimize the possible presence of membrane-bound peptides and fluorescence was measured with excitation at $485 \mathrm{~nm}(20 \mathrm{~nm}$ bandwidth) and emission at $535 \mathrm{~nm}$ ( $25 \mathrm{~nm}$ bandwidth) with a gain of 60 . If indicated, protein-treated cells were washed vigorously with PBS three times and treated with trypsin-EDTA for removal of membrane-bound proteins, then fluorescence of cell lysate was measured.

\subsection{Fluorescence microscopy}

For live cell analysis, cell penetration was visualized using confocal laser microscopy (EZ-C1, Nikon, Japan). HeLa cells were seeded on 8 well chamber slide (Nunc Lab-Tek, Thermo Scientific) and were incubated overnight. FITC-linked peptide or protein was added to the culture medium and was incubated for $4 \mathrm{~h}$ at $37^{\circ} \mathrm{C}$ in a humidified atmosphere of $5 \% \mathrm{CO}_{2}$. Nuclei of cells were then stained with Hoechst 33342 for $10 \mathrm{~min}$. Cells were washed vigorously with PBS three times to minimize the possible presence of membrane-bound peptides and then live cell intracellular fluorescence images were taken by the manufacture's software (Nikon, Japan).

For immunocytochemistry, HeLa cells were incubated with protein for $4 \mathrm{~h}$ and were then washed vigorously with PBS three times. Fixation was carried out with $4 \%$ paraformaldehyde for $20 \mathrm{~min}$, followed by $10 \mathrm{~min}$ incubation with $0.25 \%$ Triton $\mathrm{X}-100$ in PBS for permeabilization. The fixed cells were blocked with $3 \%$ BSA in $0.1 \%$ PBS-T for $1 \mathrm{~h}$. The cells were then incubated with the anti-T7 tag rabbit antibody (Abcam, Cambridge, UK) and Rhodopsin-conjugated anti-rabbit antibody (Jackson ImmunoResearch, West Grove, PA, USA). Nuclei of cells were stained with Hoechst 33342 for $10 \mathrm{~min}$. A confocal laser microscope was used to observe intracellular fluorescence and images were taken by the manufacture's software (Nikon, Japan).

\subsection{In vivo penetration of Pep-c19}

To investigate the in vivo penetration of Pep-c19, GFP-30Kc19 and GFP-Pep-c19 proteins were each dissolved in PBS and intraperitoneally injected to 5-week-old female ICR mice with an average weight of about $25 \mathrm{~g}(3.5 \mu \mathrm{mol} / \mathrm{kg})$. Following $12 \mathrm{~h}$ incubation time, mice were euthanized and organs were collected. Then, the organs were frozen with optimal cutting temperature (OCT, Miles Laboratories, Elkhart, IN, USA) compound and tissues were sectioned at a thickness of $10 \mu \mathrm{m}$ using microtome-cryostat (Microm, Walldorf, Germany) and were stored at $-70^{\circ} \mathrm{C}$ until further analysis for confocal microscopy.

\subsection{In vivo toxicity analysis}

To investigate the in vivo toxicity of Pep-c19, serum biological parameters were determined. 30Kc19 protein and Pep-c19 were dissolved in PBS and were intraperitoneally injected to 5-week-old female ICR mice with an average weight of about $25 \mathrm{~g}(0.2 \mu \mathrm{mol} / \mathrm{kg}$ or $2 \mu \mathrm{mol} / \mathrm{kg})$. Mice were euthanized after 14 days, and blood samples were collected by heart-puncture method, and were maintained in serum separating tube (SST) at room temperature for $30 \mathrm{~min}$. Following centrifugation for $10 \mathrm{~min}$ at $300 \times \mathrm{g}$ to obtain serum, samples were analyzed. As a parameter of kidney function, blood urea nitrogen (BUN) and creatinine levels were determined. 
For liver function, serum aspartate aminotransferase (AST) and alanine aminotransferase (ALT) activities were determined. The blood samples were delivered to Neodin Medical Institute (Seoul, Korea) where all biological parameters were determined and analyzed.

\subsection{Inhibitor of endocytosis}

HeLa cells were pre-incubated for $1 \mathrm{~h}$ with various inhibitors of endocytosis, prior to the experiment. $25 \mu \mathrm{M}$ cytochalasin B (Sigma-Aldrich) was used for the disruption of microfilaments and thus inhibition of macropinocytosis. $100 \mathrm{mM}$ sucrose (Sigma-Aldrich) was used for the inhibition of clathrin-mediated endocytosis. $25 \mu \mathrm{g} / \mathrm{ml}$ nystatin (Sigma-Aldrich), a sterol-binding agent, was used for disruption of caveolar structure and function. The agents were present during the entire experiment and incubation was performed for $6 \mathrm{~h}$, after which cells were vigorously washed 3 times with PBS and analyzed using spectrofluorometer in order to determine the intracellular penetration.

\section{Results and discussion}

\subsection{Presence of CPP in the $30 K c 19$ protein}

$30 \mathrm{Kc} 19$ protein, comprised of 239 amino acids in total, has all- $\alpha$ helix in $\mathrm{N}$-terminal domain and all- $\beta$ sheet in $\mathrm{C}$-terminal domain as shown in Fig. 1A [65,66]. Recently, our group has shown cellpenetrating property in various types of cells, as well as the ability to deliver cargo proteins into the cells when supplemented to culture medium. It was found to be the first cell-penetrating protein in insect hemolymph that exhibited a cell-penetration property both in vitro and in vivo [67]. In this study, we first investigated the presence of CPP within the 30Kc19 protein. To determine whether penetration of $30 \mathrm{Kc} 19$ is dependent on the structure of the protein itself, and to confirm the presence of CPP in the 30Kc19 protein, $\mathrm{N}$ - and C-terminal truncated forms of 30Kc19 protein were constructed (Fig. 1B), expressed and purified. The soluble forms of $30 \mathrm{Kc} 19_{1-120}$ and $30 \mathrm{Kc} 19_{121-239}$ were seen from the Western-blot analysis (Fig. 1C). However, 30Kc19 $1-120$ was expressed more as soluble form and 30Kc19 121-239 was expressed less as soluble form.
This indicates that $30 \mathrm{Kc} 19_{121-239}$ is mostly produced as misfolded proteins; inclusion bodies and refolding into bioactive forms is necessary. Hence only soluble forms of proteins were used. HEK 293 cell was used for Western-blot analysis as in previous study to compare the cell-penetrating ability of 30Kc19 $9_{1-120}$ and 30Kc19 $121-239$ with the $30 \mathrm{Kc} 19$ protein [67]. When cells were incubated with soluble form of N-terminal truncated 30Kc19 (30Kc191-120) at both $37^{\circ} \mathrm{C}$ and $4{ }^{\circ} \mathrm{C}, 30 \mathrm{Kc} 19_{1-120}$ protein was found in the cell (Fig. 1D). Unlike the $30 \mathrm{Kc} 19_{1-120}$ protein, $30 \mathrm{Kc} 19_{121-239}$ protein was not found in the cell and further experiments were not carried out (data not shown). This raised a question of the possible presence of a cell-penetrating peptide within the $30 \mathrm{Kc} 19$ protein. It was likely that the N-terminal truncated domain was responsible for the cellpenetrating property of $30 \mathrm{Kc} 19$ protein, which meant that CPP may exist in this domain.

\subsection{Computational analysis for identification of CPP}

We predicted the possible location of CPP within the 30Kc19 protein. Most CPPs have common characteristics, in that they have relatively high positive charge from basic amino acids such as arginine and lysine, and also have relatively high hydrophobicity from hydrophobic residues [1,2]. Also, taking penetratin from Antennapedia into account, we have evaluated that CPPs are also likely to be found in the secondary structure of helix motif and surface with relatively high accessibility $[68,69]$. Thus, we analyzed the 30Kc19 sequence that has a high frequency of basic amino acids, as well as hydrophobic amino acids in close proximity, and we managed to identify 3 domains that have the possibility of being CPP candidates; $30 \mathrm{Kc} 19_{28-39}, 30 \mathrm{Kc} 19_{45-55}$, and $30 \mathrm{Kc} 19_{113-126}$ (Fig. 2A). Next, we examined whether these 3 CPP candidates fall into distinct categories using computational analyses. To determine if CPPs are located in helix motif, the secondary structure of 30Kc19 was analyzed using the CLC protein workbench program. Through this
A

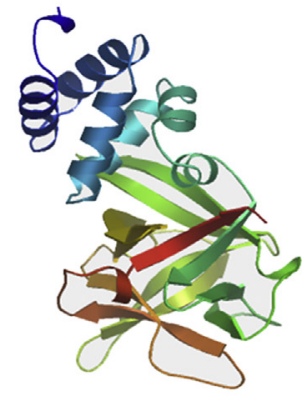

C

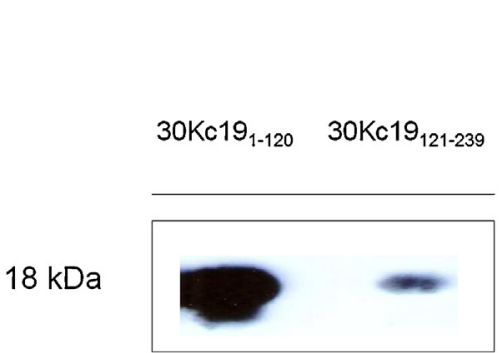

B

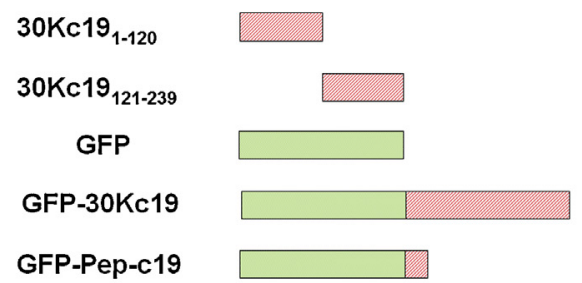

D

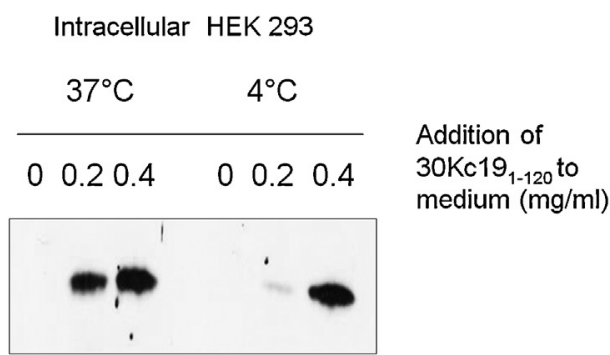

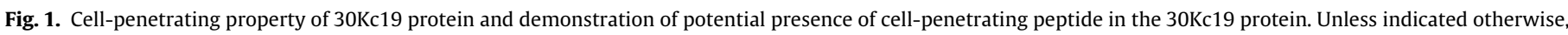

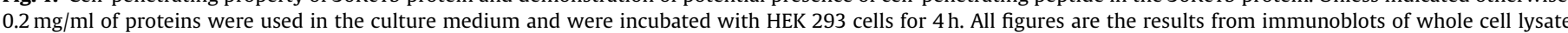

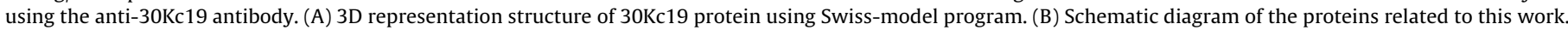

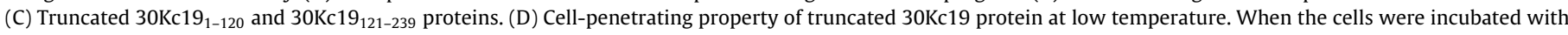
$30 \mathrm{Kc} 19_{1-120}$ at $4{ }^{\circ} \mathrm{C}$ as well as $37^{\circ} \mathrm{C}, 30 \mathrm{Kc} 19$ protein was detected in both cases. 
A

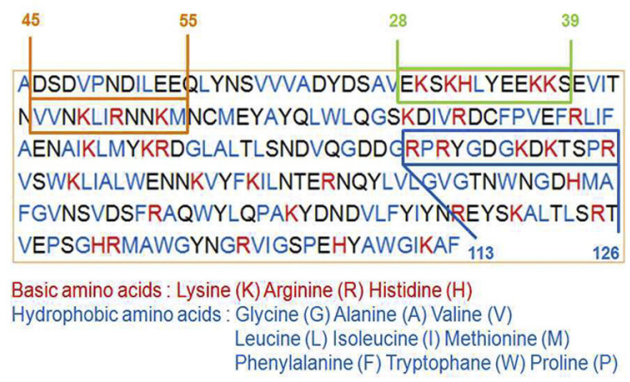

C

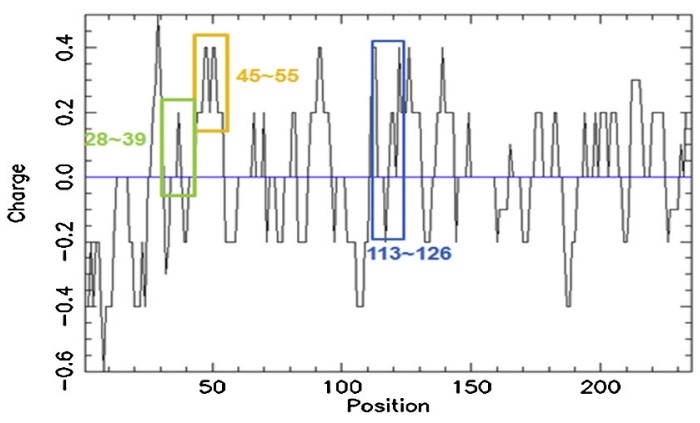

B

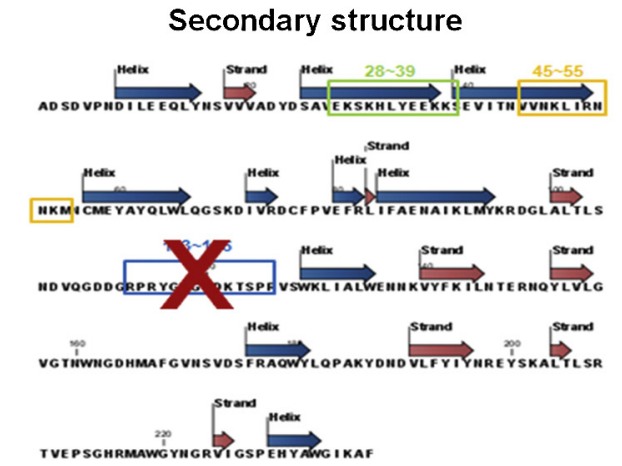

D

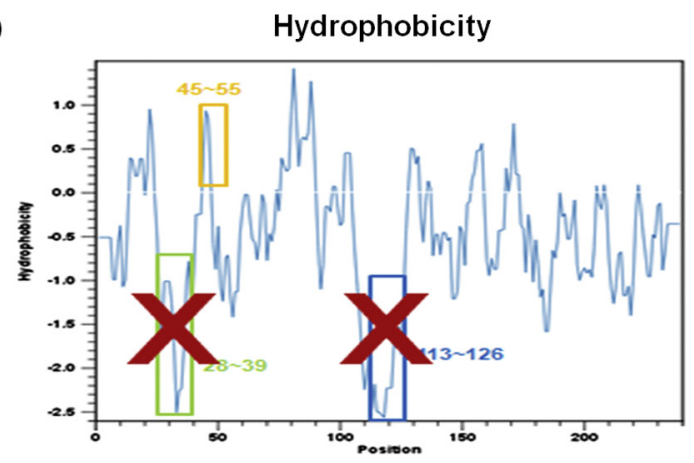

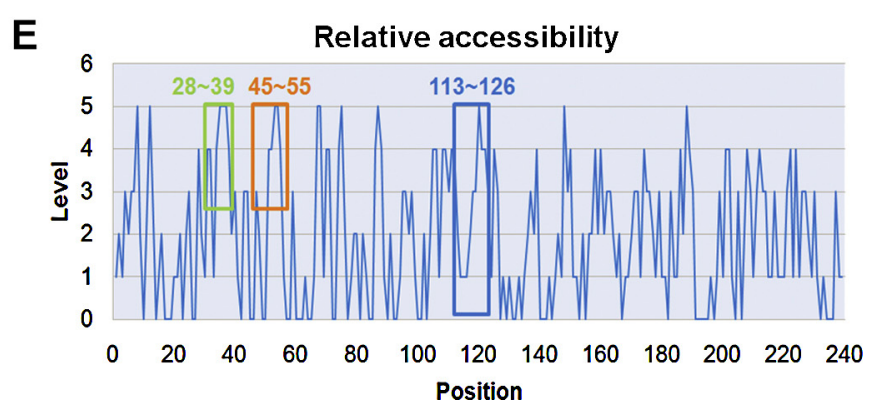

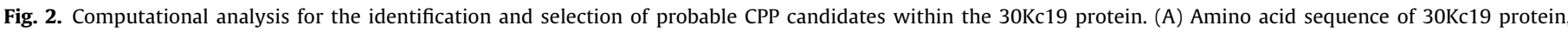

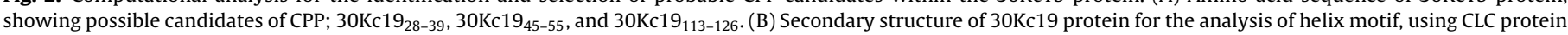

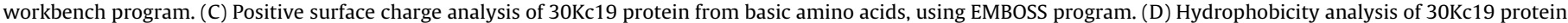
from hydrophobic amino acids, using CLC protein workbench program. (E) Surface accessibility analysis of $30 \mathrm{Kc} 19$ protein, using LOOPP program.

analysis, only $30 \mathrm{Kc} 19_{28-39}$ and $30 \mathrm{Kc} 19_{45-55}$ had a high possibility of being helix motif (Fig. 2B). Then we examined the net charge of these CPP candidates using the EMBOSS program. From the analysis, it was found that $30 \mathrm{Kc}_{1} 9_{45-55}$ showed the greatest net positive charge of all CPP candidates (Fig. 2C). In addition, the hydrophobicity of 30Kc19 protein was predicted using the CLC protein workbench program. From the analysis, only $30 \mathrm{Kc}^{1} 9_{45-55}$ showed higher hydrophobicity than the other two CPP candidates (Fig. 2D). Lastly, the relative surface accessibility of 30Kc19 protein was performed using LOOPP program. From the analysis, all CPP candidates were determined to have similar surface accessibility (Fig. 2E). The results from several computational analyses; helix motif, positive surface charge, hydrophobicity, and relative surface accessibility showed that only $30 \mathrm{Kc} 19_{45-55}$ satisfied the characteristics and hence, it was selected as being the most probable candidate for the CPP within in the $30 \mathrm{Kc} 19$ protein.

\subsection{Quantitative uptake of peptides for identification of CPP}

In order to examine whether this region of $30 \mathrm{Kc} 19$ domain encompasses CPP, 17 peptides conjugated with FITC were synthesized (Fig. 3A). We extended the peptide sections starting from 41 to 57 because of hydrophobic amino acids at 41 (Val) and 42 (Ile), and Cys at 57. We expected hydrophobic amino acid is an important factor because Antp $43-58$ sequence (RQIKIWFQNRRMKWKK) contains 6 hydrophobic amino (Ile, Ile, Trp, Phe, Met, Trp) acids in total. We also expected that cysteine may be an important factor because of previous report that it may be involved in the process of internalization via formation of dimer [70]. HeLa cell was used for intracellular fluorescence analysis as in previous study [67]. With the aim of narrowing down our search for cell-penetrating peptide, each FITC-linked peptide was added to culture medium and cells were later washed vigorously with PBS several times to remove any cell-bound peptides. Intracellular fluorescence from each peptide was measured using a spectrofluorometer. Out of 3 sections; $30 \mathrm{Kc} 19_{x-55}, 30 \mathrm{Kc} 19_{x-56}$, and $30 \mathrm{Kc} 19_{x-57}$, each showed high fluorescence, as indicated (Fig. 3B). However, because washes in PBS may not be sufficient to remove some membrane-bound peptides, 2 peptides from each section were selected (red arrow), and thus, 6 peptides; $30 \mathrm{Kc}_{1} 9_{41-55}, 30 \mathrm{Kc} 19_{42-55}, 30 \mathrm{Kc} 19_{41-56}, 30 \mathrm{Kc} 19_{42-56}$, $30 \mathrm{Kc} 19_{44-57}, 30 \mathrm{Kc} 19_{45-57}$ were closely examined for their cellpenetrating ability by using confocal microscopy. The results showed that 2 peptides; $30 \mathrm{Kc} 19_{44-57}$ and $30 \mathrm{Kc} 19_{45-57}$, were visualized in cytoplasm and were able to penetrate the plasma membrane (Fig. 3C). The results are similar to HIV-TAT and Antp [71,72]. On the other hand, 4 peptides; $30 \mathrm{Kc}_{1} 9_{41-55}, 30 \mathrm{Kc}_{1} 9_{42-55}, 30 \mathrm{Kc} 19_{41-56}$ 
A

FITC-linked 41 VITNVVNKLIRNNKM 55 FITC-linked 42 ITNVVNKLIRNNKM 55 FITC-linked 43 TNVVNKLIRNNKM 55 FITC-linked 44 NVVNKLIRNNKM 55 FITC-linked 45 VVNKLIRNNKM 55

FITC-linked 41 VITNVVNKLIRNNKMN 56 FITC-linked 42 ITNVVNKLIRNNKMN 56 FITC-linked 43 TNVVNKLIRNNKMN 56 FITC-linked 44 NVVNKLIRNNKMN 56 FITC-linked 45 VVNKLIRNNKMN 56

FITC-linked 41 VITNVVNKLIRNNKMNC 57 FITC-linked 42 ITNVVNKLIRNNKMNC 57 FITC-linked 43 TNVVNKLIRNNKMNC 57 FITC-linked 44 NVVNKLIRNNKMNC 57 FITC-linked 45 VVNKLIRNNKMNC 57 FITC-linked 46 VNKLIRNNKMNC 57 FITC-linked 47 NKLIRNNKMNC 57
C
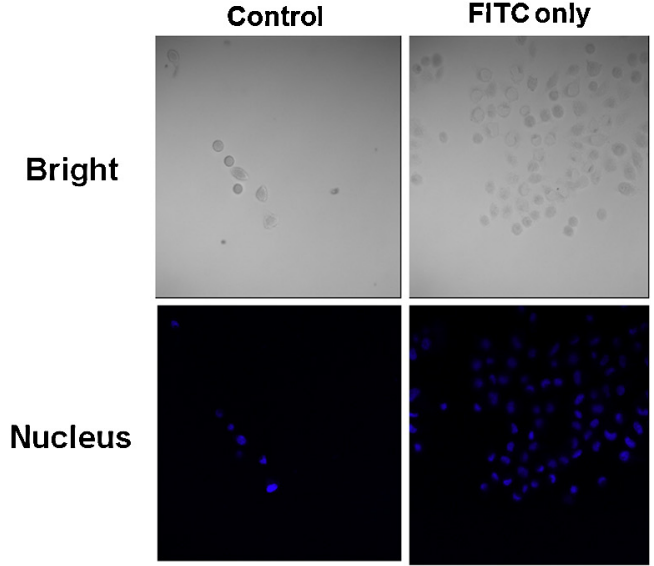

FITC only
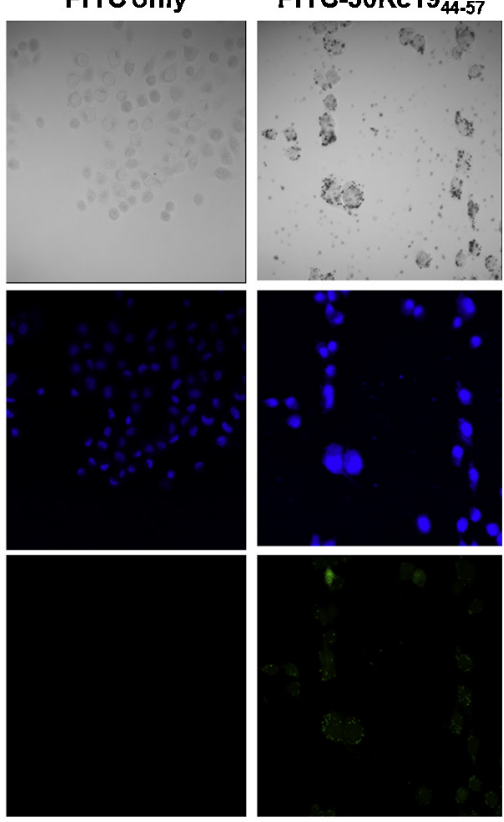

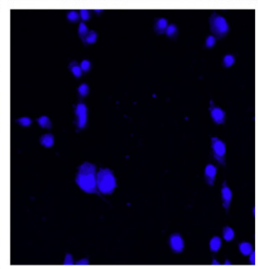

FITC-30Kc19 ${ }_{44-57}$

FITC-30Kc19 ${ }_{45-57}$
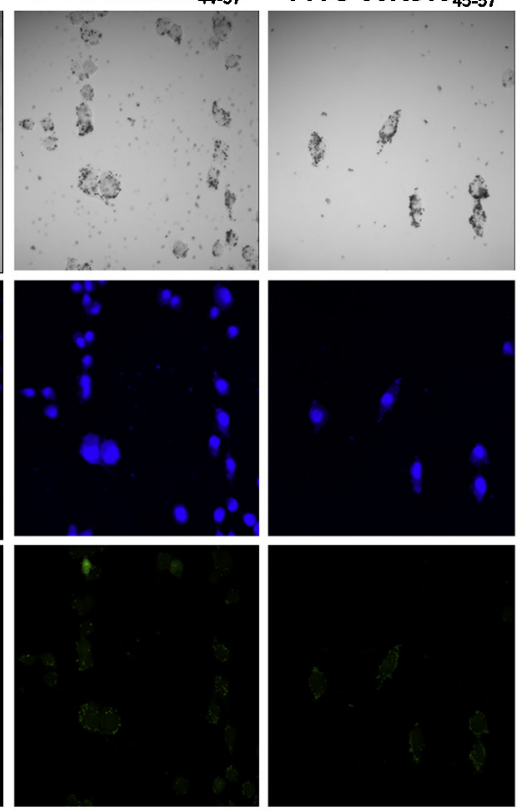

B

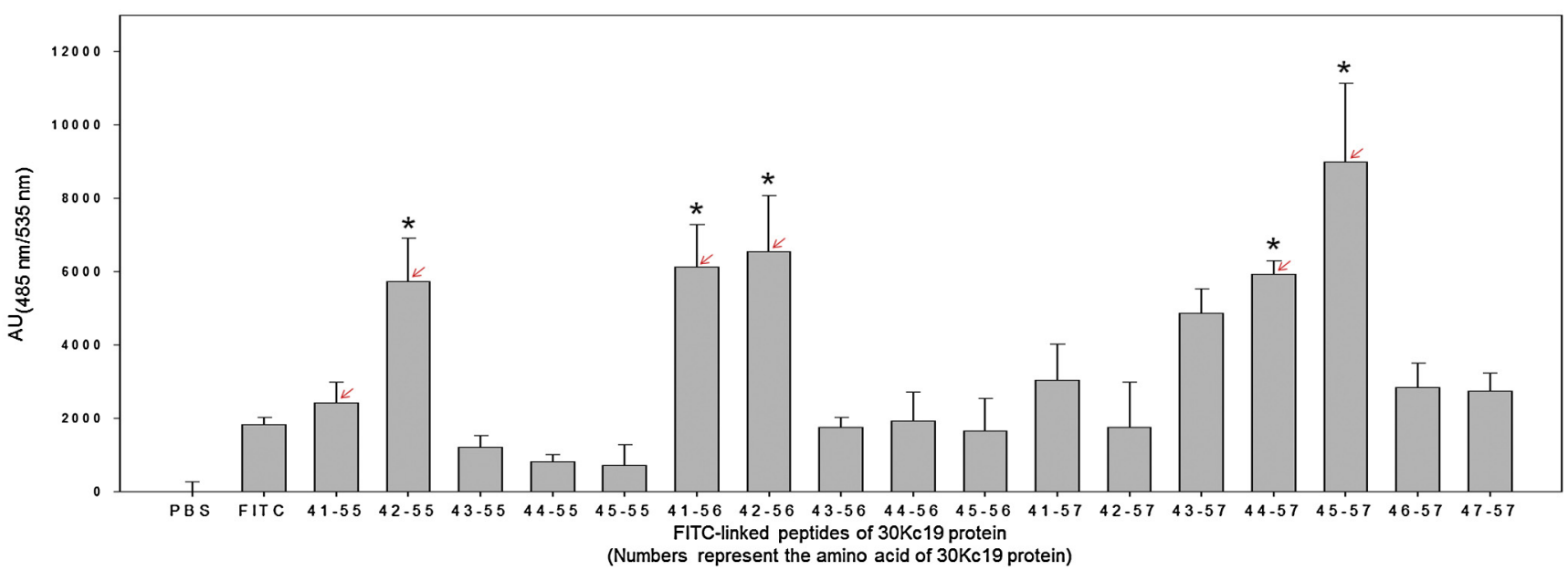

Fig. 3. Identification of Pep-c19. (A) FITC-linked peptides were selected based on the computational results from the most probable CPP candidate; $30 \mathrm{Kc} 19_{45-55}$, for the cell-penetrating ability. (B) Intracellular fluorescence of $30 \mathrm{Kc} 19_{x-y}$ CPP candidates was measured using spectrofluorometer $(\mathrm{ex} .485 \mathrm{~nm} / \mathrm{em} .535 \mathrm{~nm}) .{ }^{*} p<0.001$, compared with the FITC-treated group $(n=6)$. Error bars represent standard deviation. Arrows indicate the peptides selected for confocal microscopy analysis. (C) Confocal microscopy image of the cell internalization of $30 \mathrm{Kc} 19_{x-y}$ CPP candidates in living cells. In all cases, HeLa cells were incubated for $4 \mathrm{~h}$ with the same molar concentration of $30 \mathrm{Kc} 19_{x-y}$ peptides $(10 \mu \mathrm{M})$, and were washed 3 times with PBS. The cell internalization of $30 \mathrm{Kc} 19_{x-y}$ peptides were visualized by FITC fluorescence (Green) and nuclei were visualized by Hoechst 33342 (Blue). $x$ and $y$ denote the amino acid number of 30Kc19 protein.

and $30 \mathrm{Kc} 19_{42-56}$, were unable to penetrate the cell, and some actually formed membrane-bound aggregates (data not shown), which could explain the fluorescence given out in Fig. 3B. The formation of aggregates could have risen from the hydrophobic amino acids; Val-41 and Ile-42, where the number of hydrophobic amino acids in those 4 peptides was too many to allow for stability and solubility in the culture medium. $30 \mathrm{Kc} 19_{45-57}$ is shorter in length than $30 \mathrm{Kc} 19_{44-57}$, and thus, $30 \mathrm{Kc} 19_{45-57}$ was chosen as the CPP of 30 Kc19 protein. Thus, 30 Kc $19_{45-57}$, which will be named "Pep-c19", was found to be the cell-penetrating peptide from 30Kc19 protein that efficiently penetrated cells when supplemented into medium for mammalian cell culture.

\subsection{Cellular protein delivery of protein-conjugated Pep-c19}

In order to examine the ability of Pep-c19 to deliver foreign proteins into the cell as well as its cell-penetrating efficiency, a GFP-Pep-c19 as well as GFP and GFP-30Kc19 was expressed in E. coli and purified (Fig. 4A). HeLa cell was used for fluorescence analysis as in previous study to compare the cargo-delivering ability of Pep-c19 with the $30 \mathrm{Kc} 19$ protein [67]. Each protein was added to culture medium of HeLa cells and the increase in intracellular GFP-Pep-c19 was determined to be dependent on the concentration of the protein in the culture medium. The efficiency of the Pep-c19 was higher than the GFP-30Kc19, even after vigorous washing with PBS for the removal of any cell-bound proteins (Fig. 4B). The increase in the intracellular penetrated GFP-Pep-c19 was dependent on the time of the protein in the culture medium, and the efficiency of the Pep-c19 was also higher than the GFP-30Kc19, after vigorous washing with PBS (Fig. 4C). Then, each protein was added to the culture medium of HeLa cells and immunocytochemistry was performed. Similar to GFP30Kc19, GFP-Pep-c19 also penetrated into the cells. Live cell images were taken under confocal microscope after vigorous washing with 
A

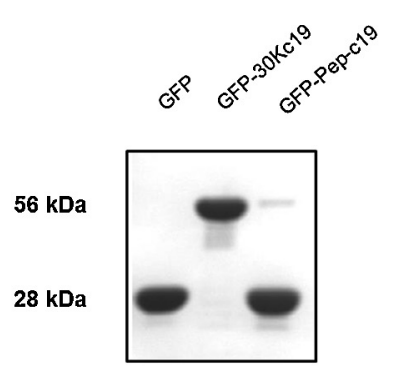

B

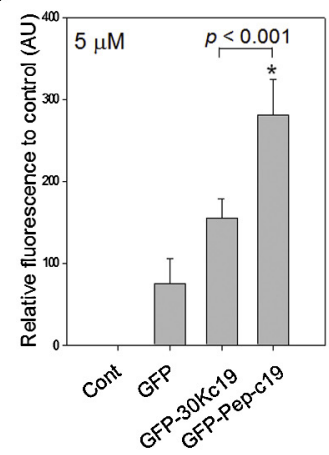

C

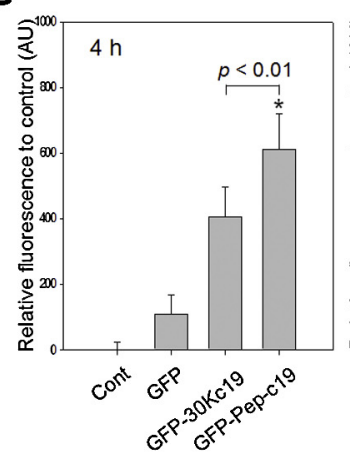

D

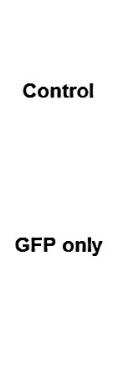

GFP-30Kc19
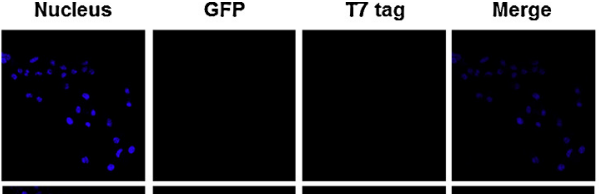

GFP-Pep-c19
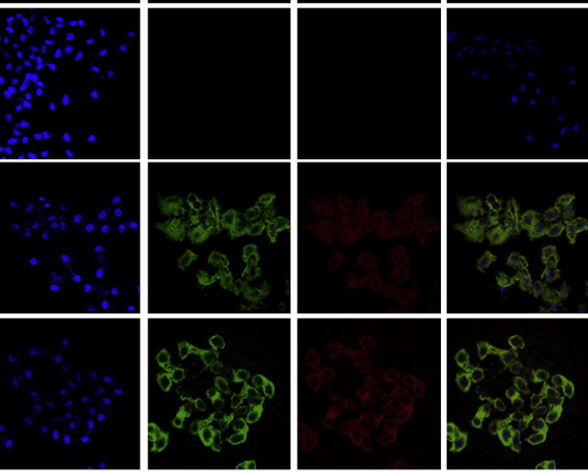

E
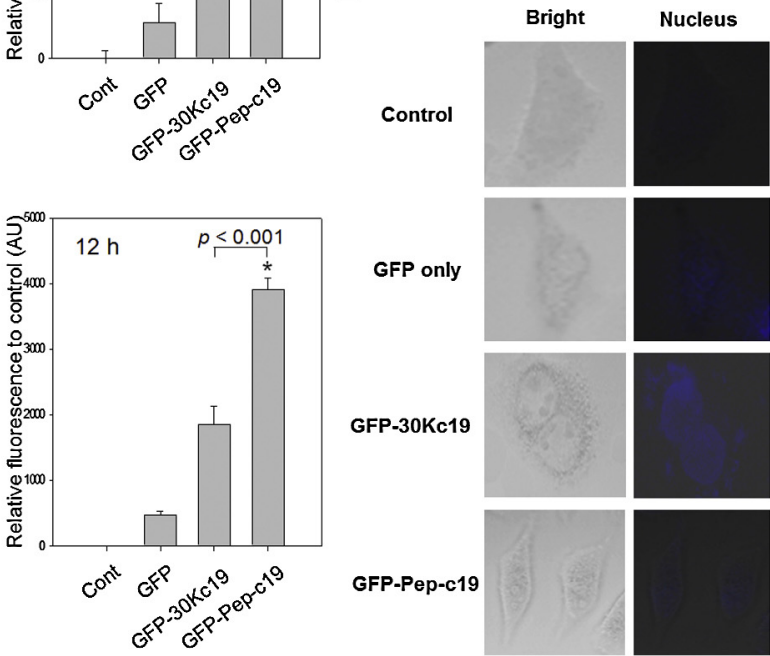
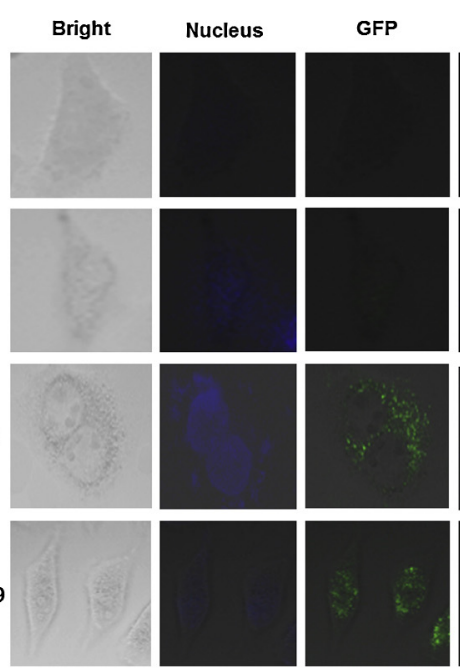

$\mathbf{F}$

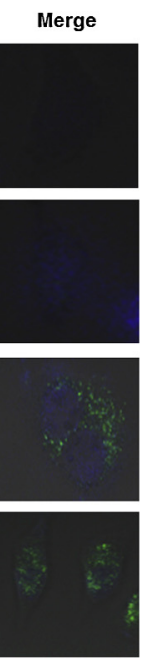

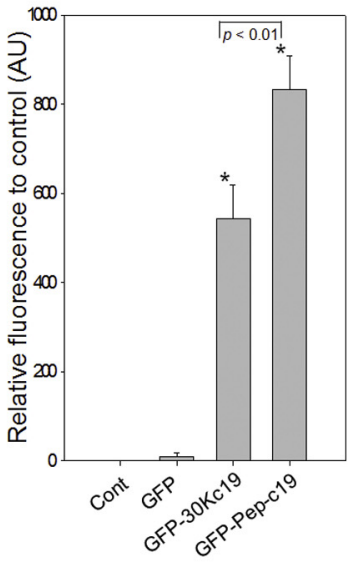

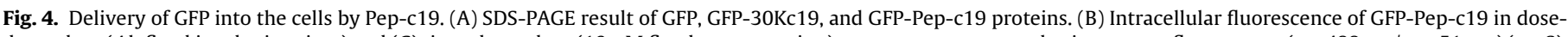

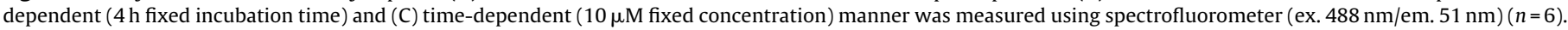

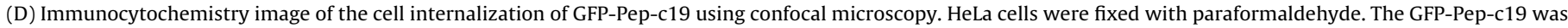

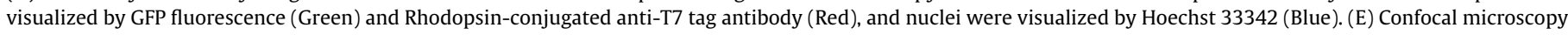

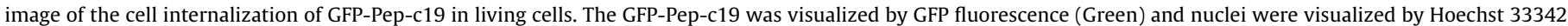

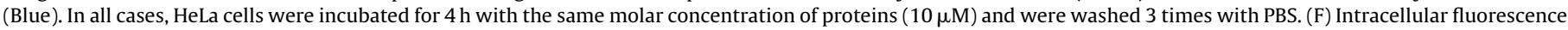

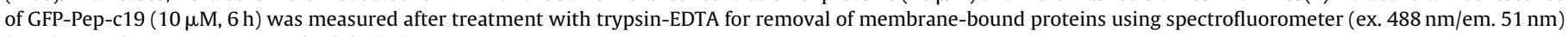
$(n=3)$. Error bars represent standard deviation.

PBS to exempt membrane-bound proteins and possible artifacts from fixation process of immunocytochemistry, where cell surfacebound proteins could be moved into cells [73]. The confocal images indicated that GFP-Pep-c19 successfully penetrated inside the living cells (Fig. 4E). Similar to Fig. 3C, it was worthwhile to notice that GFP-Pep-c19 was visualized in a punctate form. It was shown that internalized foreign proteins fused with the cell-penetrating peptide were observed as punctate forms [72,74]. Quantification of the intracellular fluorescence from the cell lysate was performed to fully exclude the possible membrane-bound proteins. Protein-treated cells were treated with trypsin-EDTA for removal of membrane-bound proteins and then fluorescence of cell lysate was measured (Fig. 4F). The result showed that both GFP-30Kc19 and GFP-Pep-c19 proteins were located in the cell lysate, but more GFP-Pep-c19 was found inside the cell. These results demonstrated that Pep-c19 can, not only penetrates itself, but it is also able to deliver impermeable cargo proteins, such as GFP into the cell with higher efficiency than the whole 30Kc19 protein.

\subsection{In vivo protein delivery of protein-conjugated Pep-c19}

Previously, CPPs have been used to successfully deliver cellimpermeable cargos such as proteins [3-6], small molecules [7-9], nucleic acids [10-12], antibodies [13,14], and nanoparticles [15-18] both in vitro and in vivo. To investigate in vivo penetration and efficiency in comparison with the whole 30Kc19 protein, we intraperitoneally injected each protein to 5-week-old ICR mice, and the organs, including brain, heart, lung, kidney, and liver, were isolated $12 \mathrm{~h}$ after injection [75-77]. In order to avoid an artifact and to address the potential issue caused by fixation process from immunohistochemistry, fluorescence images were taken without the fixation process, and thus, the penetration of GFP-Pep-c19 into tissues was analyzed by the fluorescence from the GFP protein. No fluorescence was detected for the native GFP in tissues (Fig. 5, top panel). Fluorescence was detected in all the tissues isolated from the mouse that were injected with GFP-30Kc19, although the fluorescence intensities varied among tissues (Fig. 5, middle panel). 
A

Heart

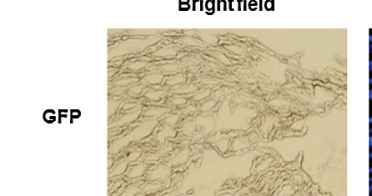

GFP.

$30 \mathrm{Kc19}$

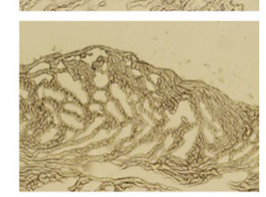

GFP.

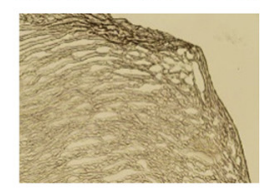

C

Kidney
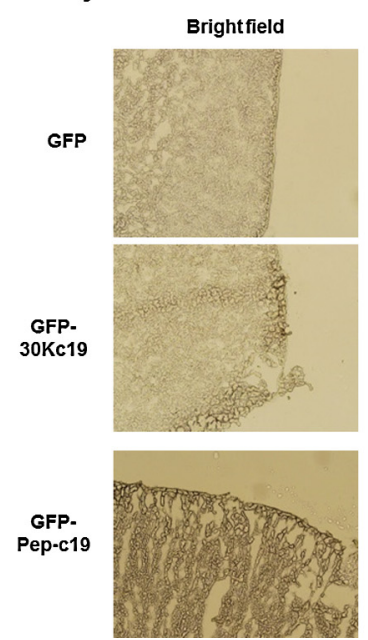

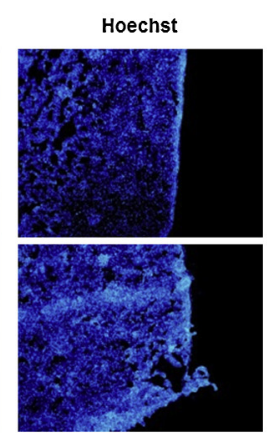

Hoechst
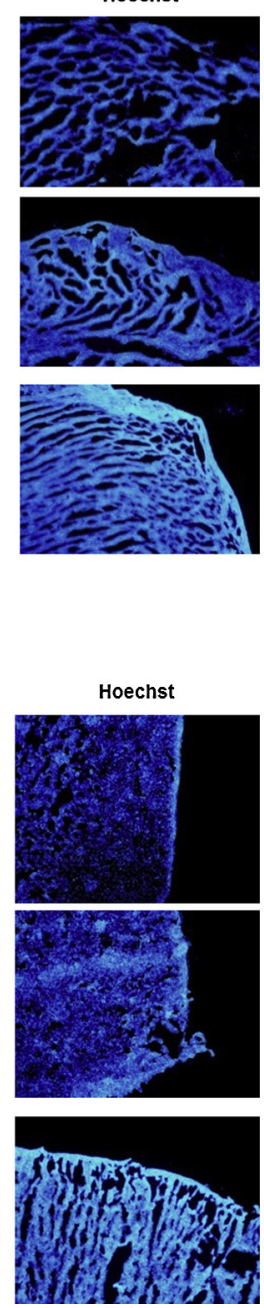

Fluorescence
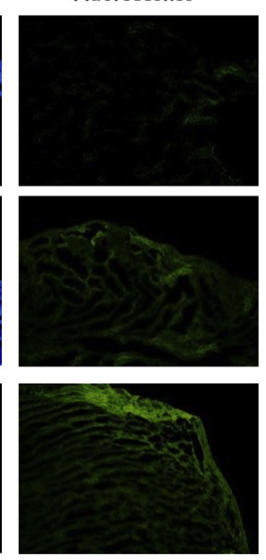

GFP.
Pep-c19

GFP.
Lung
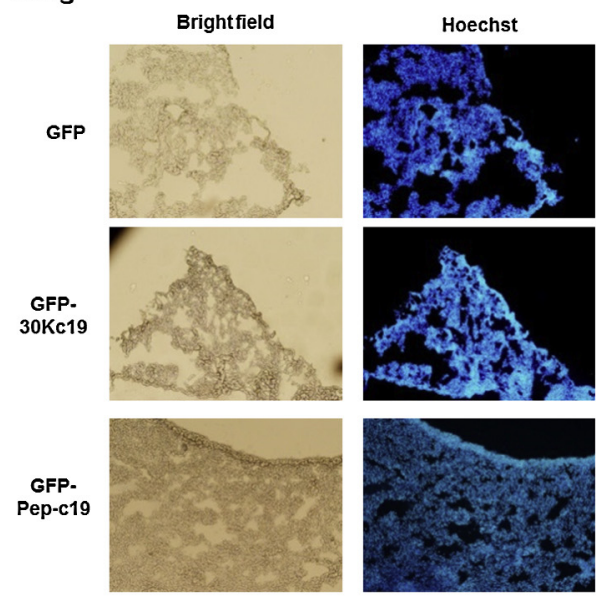

D

\section{Liver}
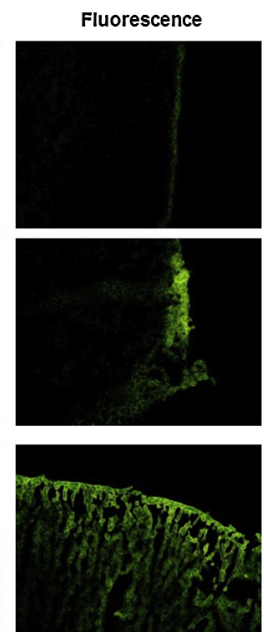
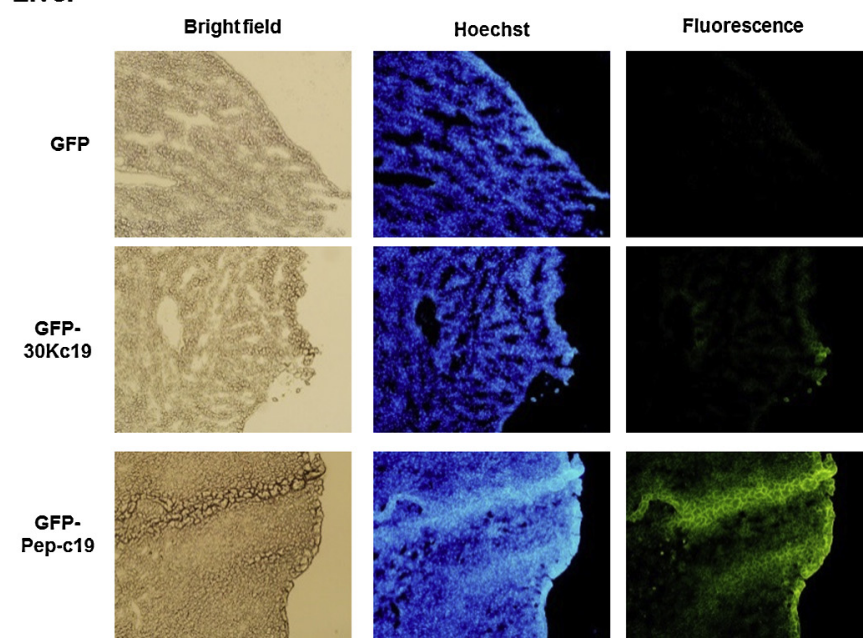

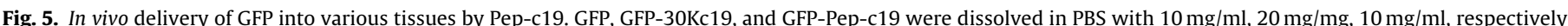

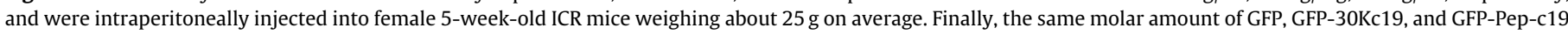

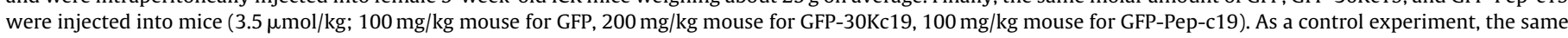

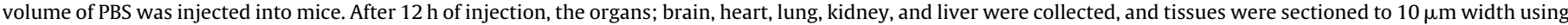

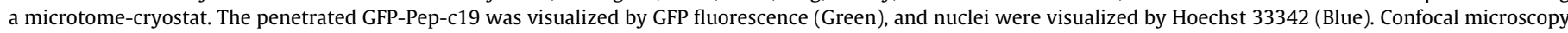
images of the tissue internalization of GFP-Pep-c19 in living tissues of brain, heart, lung, kidney, and liver are presented in (A), (B), (C) and (D), respectively.

On the contrary, for GFP-Pep-c19, we observed that fluorescence intensity was much higher than that from GFP-30Kc19 in tissues (Fig. 5, bottom panel). This indicates that Pep-c19 penetrated and delivered cargo into various tissues across the blood vessel barriers with a high efficiency.

\subsection{Toxicity test}

We have previously shown that $30 \mathrm{~K}$ proteins do not show any toxic effect in vitro cell cultures and in vivo study $[45,48,51,52,67]$. To examine in vivo toxicity of Pep-c19, we measured the toxicity parameters that represent toxicity in kidney and liver. Toxicity in kidney is shown by increase in the levels of blood urea nitrogen (BUN) and creatinine, whereas toxicity on liver is shown by increase in the levels of aspartate aminotransferase (ALT) and alanine aminotransferase (AST) [78,79]. The level of BUN, creatinine, ALT and AST from the blood serum of Pep-c19-injected mice were analyzed by Neodin Institute. We injected 3 different mice with $0.2 \mu \mathrm{mol} / \mathrm{kg}$ and $2 \mu \mathrm{mol} / \mathrm{kg}$ of each protein, every day, for
14 days, and evaluated the toxicity. After 2 weeks of injection, no apparent differences in the body weights and behaviors of mice were observed in any of the groups (data not shown). Toxicity results showed that high dose and long-term administration of Pep-c19 did not cause statistically significant or meaningful differences between 30Kc19 protein and Pep-c19 from all four toxicity parameters (Fig. 6). In all tests, the p-values between the control group and the 30Kc19-injected group and Pep-c19-injected group were mostly higher than 0.1 . These results indicate that long-term administration of Pep-c19 did not cause significant toxicity in vivo. Previously, it was reported that Tat and VP22 are non-toxic both in vitro [80-82] and Tat is non-toxic in vivo [75]. In another group, toxicity was evaluated in vivo by applying peptides to the cornea 4 times daily for 7 days. At very high concentrations, the Antennapedia peptide showed no toxicity, whereas Tat caused some mild eyelid swelling [83]. The results in Fig. 6 show that Pep-c19 has similar non-toxic property. Therefore, it is anticipated that Pep-c19 could be utilized as an efficient and nontoxic carrier for the delivery of biological molecules into tissues in vivo. Other than fusing the CPP 
A

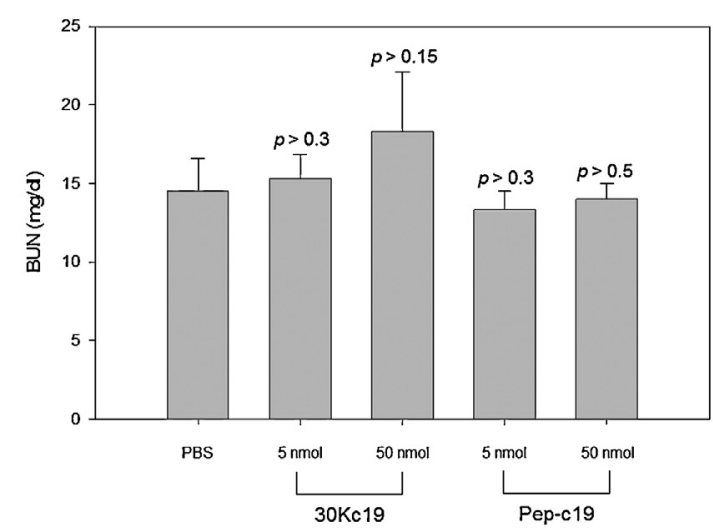

C

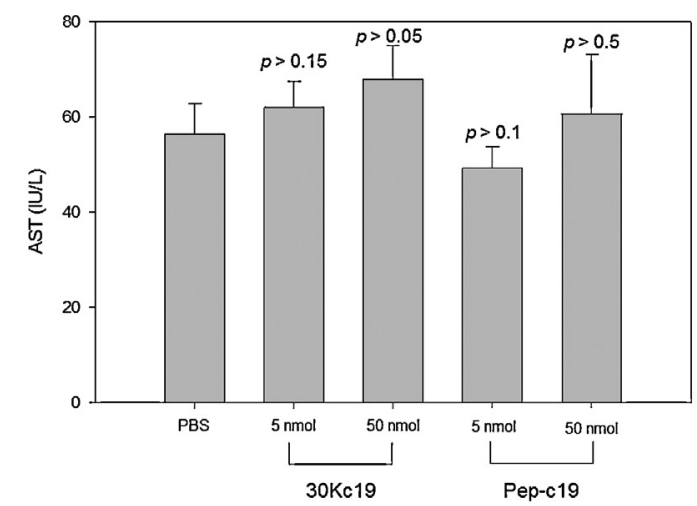

B

Creatinine

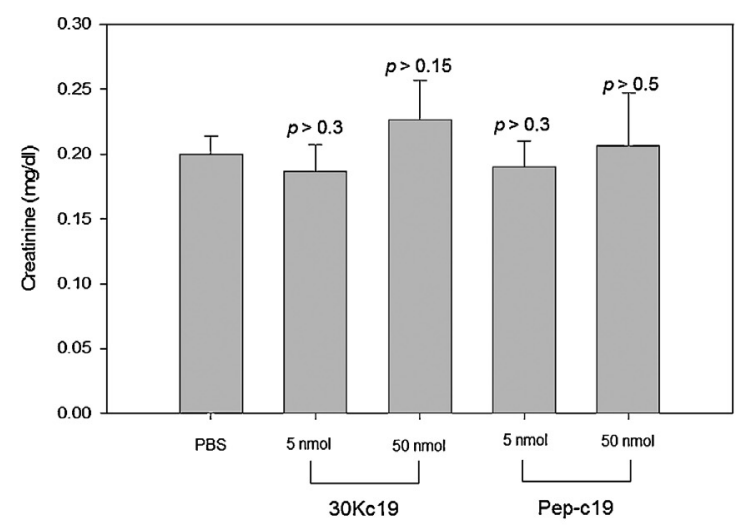

ALT

D

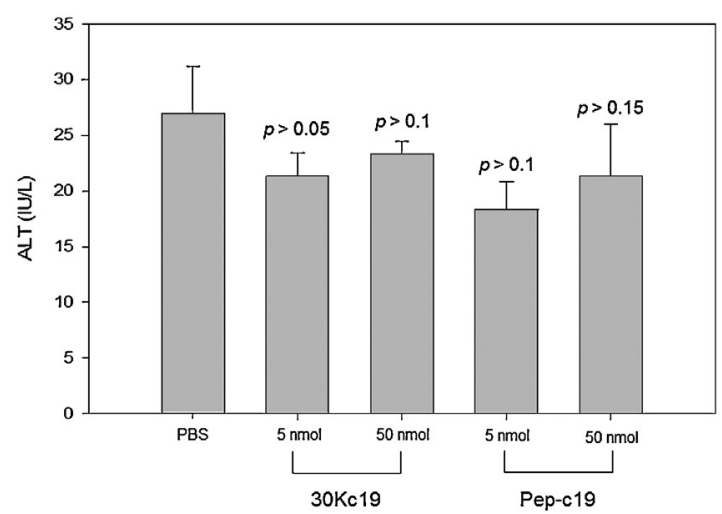

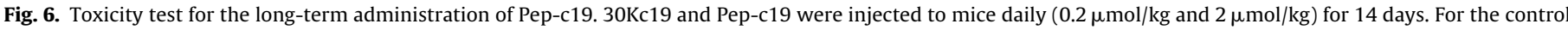

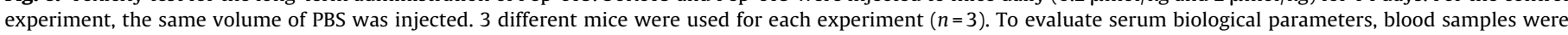

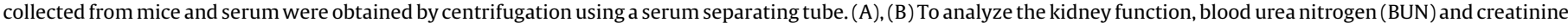

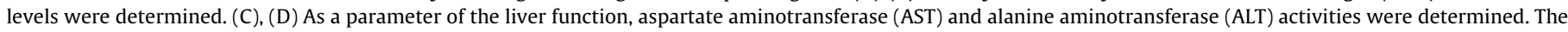
$p$-values on each bar were evaluated by comparing with the control group (PBS-treated). Error bars represent the standard deviation.

with the cargo, the non-conjugation approach may also be adapted for the delivery of cell-impermeable cargos; for instance siRNA, by mixing the CPP and siRNA and forming CPP/siRNA complex.

\subsection{Intracellular penetration Pep-c19 CPP in the presence of inhibitors of endocytosis}

It was notable that Pep-c19 successfully penetrates into cells and tissues upon addition to culture medium and intraperitoneal injection to mice, respectively. However, the mode of intracellular penetration was still unknown. Hence, inhibitors of endocytosis were used to find out how the Pep-c19 penetrates into cells. Prior to the treatment of FITC-Pep-c19 peptide, HeLa cells were treated with inhibitors of endocytosis; cytochalasin B, sucrose, and nystatin, for the disruption of microfilaments/inhibition of macropinocytosis, inhibition of clathrin-mediated endocytosis, and disruption of caveolar structure and function, respectively (Fig. 7) [9]. Sucrose was treated to give cells a hyperosmolar condition, but no markedly difference in the penetration ability of the Pepc19 was seen. This showed that Pep-c19 does not penetrate by clathrin-mediated endocytosis. However, when cytochalasin B or nystatin was treated to cells, slightly lowered cell-penetrating ability of the Pep-c19 was seen, which demonstrates that it penetrates cells by macropinocytosis and caveolin-mediated endocytosis. Others reported that cytochalasin B reduced the cellular uptake of CPP by half [84], and nystatin reduced the CPP reporter $\beta$-gal activity by $50 \%$ in various cells [85]. The mechanism of entry of Pep-c19 is similar to other CPPs, but Pep-c19 involves 2 uptake pathways. In our current studies, we are undergoing molecular mechanism study of Pep-c19 for clarification of endosomal escape property.

\subsection{Comparison of Pep-c19 with other cell-penetrating peptides}

Well-known cell-penetrating peptides derived from protein transduction domains are Tat from human immunodeficiency virus-1 (HIV-1) [30,31], VP22 from herpes simplex virus-1 (HSV-1) [34,35], and Antp (also known as Penetratin) from Antennapedia homeodomain $[32,33]$. In this research, we have found a new cellpenetrating peptide from the third helix of Bombyx mori silkworm hemolymph. When we compare Pep-c19 with other CPPs in terms of the primary structure, Pep-c19 CPP contains less positive amino acids ( 3 in the sequence) than other CPPs (TAT has 8, VP22 has 9, Antp; has 7) (Table 1). Instead, Pep-c19 has more hydrophobic acids (6 in the sequence) than the most of other CPPs (TAT has 0, VP22 has 1, Antp has 6). With the secondary structure, Antp's homeodomain is comprised of 60 residues and it is consisted of 3 alpha-helices. Third alpha-helix is responsible for penetration (Antp), which is similar to our Pep-c19, because it is also from the third alpha helix of the $30 \mathrm{Kc} 19$ protein. HSV-1 protein 22 has size that is a little bigger than the $30 \mathrm{Kc} 19$ protein, $38 \mathrm{kDa}$, and VP22 is located at the very last 34 residues. These CPPs have been used to transduce proteins into cells and tissues, and for some (Tat and Antp) even across blood brain barrier but efficiency various depending on the cargo that is attached to the CPPs [86]. Though advantages and disadvantages 


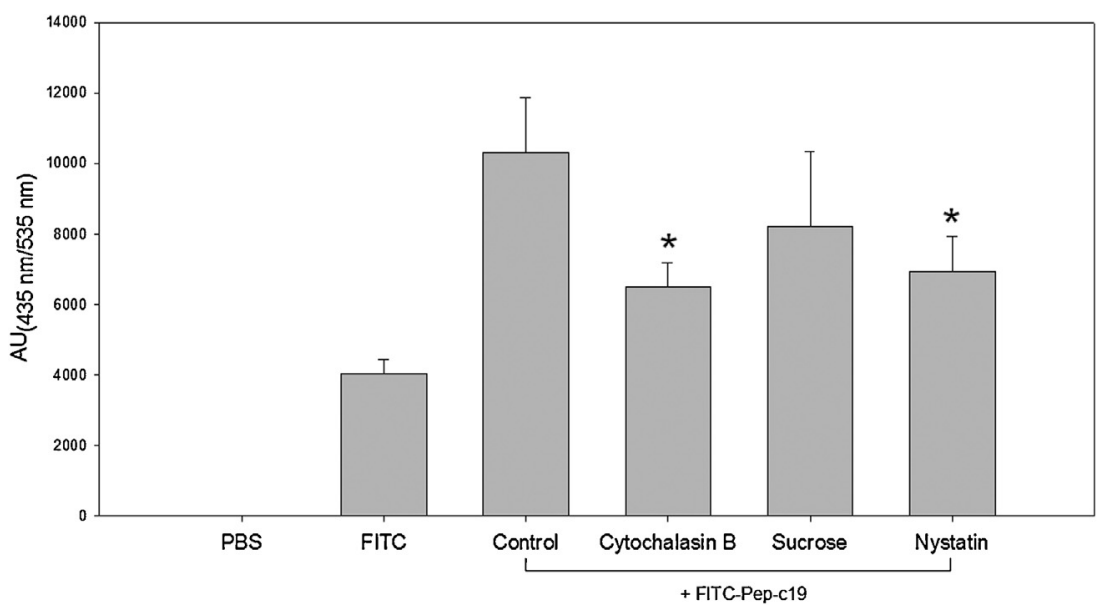

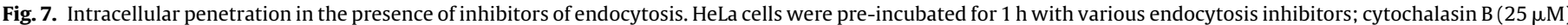

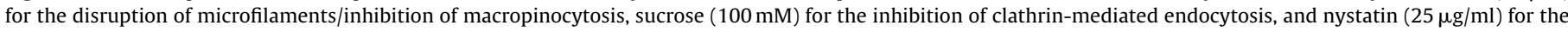

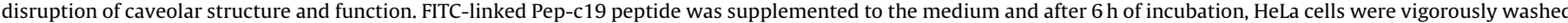

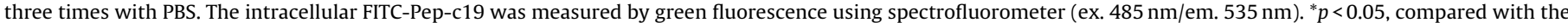
control group $(n=3)$. Error bars represent standard deviation.

Table 1

Comparison of Pep-c19 with other cell-penetrating peptides.

\begin{tabular}{|c|c|c|c|}
\hline Name & Origin & Sequence (No. of amino acid) & Features \\
\hline Tat & $\begin{array}{l}\text { Human immunodeficiency } \\
\text { virus-1 trans-activating } \\
\text { transcriptional activator } \\
\text { (HIV-1 TAT); residues 48-60 }\end{array}$ & GRKKRRQRRRPPQ (13) & $\begin{array}{l}\text { Able to transduce } 15-120 \mathrm{kDa} \text { proteins into cells with } \\
\text { high efficiency }(\sim 100 \%) \text {. In vivo delivery after } 4 \mathrm{~h} \text { into } \\
\text { various tissues and across BBB. }\end{array}$ \\
\hline VP22 & $\begin{array}{l}\text { Herpes simplex virus-1 protein } \\
22 \text { (HSV-1); residues } 266-301\end{array}$ & $\begin{array}{l}\text { DAATATRGRSAASRPTERPR } \\
\text { APARSASRPRRPVD (34) }\end{array}$ & $\begin{array}{l}38 \mathrm{kDa} \text { size with last } 34 \text { residues responsible for } \\
\text { penetration. Efficacy varies with cell type but quite } \\
\text { inefficient. }\end{array}$ \\
\hline $\begin{array}{l}\text { Antp } \\
\text { (Penetratin) }\end{array}$ & $\begin{array}{l}\text { Antennapedia homeodomain; } \\
\text { residues } 43-58\end{array}$ & RQIKIWFQNRRMKWKK (16) & $\begin{array}{l}\text { Consists of } 3 \text { alpha-helices. Third helix responsible for } \\
\text { penetration; in vivo delivery into brain within } 30 \mathrm{~min} \text {. }\end{array}$ \\
\hline $\begin{array}{l}\text { Nona- } \\
\text { arginine (R9) }\end{array}$ & Polyarginine & RRRRRRRRR (9) & $\begin{array}{l}\text { Polyarginine peptides of } 4-16 \text { residues tested with } 8 \text { and } \\
9 \text { being optimal. Able to transduce molecules into a } \\
\text { variety of cells in culture. }\end{array}$ \\
\hline Pep-c19 & $\begin{array}{l}\text { Bombyx mori } 30 \mathrm{Kc} 19 \text { protein; } \\
\text { residues } 45-57\end{array}$ & VVNKLIRNNKMNC (13) & $\begin{array}{l}28 \mathrm{kDa} \text { size with } 13 \text { residues in third helix responsible } \\
\text { for penetration; in vivo delivery into various tissues } \\
\text { except brain. }\end{array}$ \\
\hline
\end{tabular}

Red color: positive amino acid; blue color: hydrophobic amino acid [86].

exist among the CPPs, the major advantage of Pep-c19 is that it is not a virus-derived cell-penetrating peptide meaning it is applicable as a therapeutic tool, short length, and is not toxic. Currently, we are now comparing the Pep-c19 with other known CPPs for assessment of uptake efficiency, delivery kinetics and toxicity test for potential use of this Pep-c19.

\section{Conclusions}

We have identified a new CPP; VVNKLIRNNKMNC, from 30Kc19 protein and demonstrated that $30 \mathrm{Kc} 19$ exhibited a cell-penetrating property due to the presence of a cell-penetrating peptide at 45-57. Our results strongly suggest that Pep-c19 has great potential for the efficient delivery of micro- and macromolecules including drugs and proteins to target tissues for therapeutic purposes. Since Pep-c19 is a cell-penetrating peptide derived from the first cellpenetrating protein that has been found in insect hemolymph, we anticipate that other cell-penetrating peptides that have similar properties to Pep-c19 will be identified from other proteins sourced from insects.

\section{Acknowledgements}

This research was supported by the National Research Foundation of Korea (NRF) funded by the Ministry of Science, ICT \& Future Planning (2013069511).

\section{References}

[1] El-Andaloussi S, Holm T, Langel U. Cell-penetrating peptides: mechanisms and applications. Curr Pharm Des 2005;11:3597-611.

[2] Zorko M, Langel Ü. Cell-penetrating peptides: mechanism and kinetics of cargo delivery. Adv Drug Del Rev 2005:57:529-45.

[3] Fawell S, Seery J, Daikh Y, Moore C, Chen LL, Pepinsky B, et al. Tat-mediated delivery of heterologous proteins into cells. Proc Natl Acad Sci 1994;91:664-8. 
[4] Zender L, Kühnel F, Köck R, Manns M, Kubicka S. VP22-mediated intercellular transport of p53 in hepatoma cells in vitro and in vivo. Cancer Gene Ther 2002;9:489-96.

[5] Do Kwon Y, Oh SK, Kim HS, Ku S-Y, Kim SH, Choi YM, et al. Cellular manipulation of human embryonic stem cells by TAT-PDX1 protein transduction. Mol Ther 2005; $12: 28-32$.

[6] Myrberg H, Lindgren M, Langel Ü. Protein delivery by the cell-penetrating peptide YTA2. Bioconjug Chem 2007;18:170-4.

[7] Rothbard JB, Garlington S, Lin Q Kirschberg T, Kreider E, McGrane PL, et al. Conjugation of arginine oligomers to cyclosporin A facilitates topical delivery and inhibition of inflammation. Nat Med 2000;6:1253-7.

[8] Gupta B, Levchenko TS, Torchilin VP. Intracellular delivery of large molecules and small particles by cell-penetrating proteins and peptides. Adv Drug Del Rev 2005:57:637-51.

[9] Veldhoen S, Laufer SD, Trampe A, Restle T. Cellular delivery of small interfering RNA by a non-covalently attached cell-penetrating peptide: quantitative analysis of uptake and biological effect. Nucleic Acids Res 2006;34:6561-73.

[10] Chiu Y-L, Ali A, Chu C-y, Cao H, Rana TM. Visualizing a correlation between siRNA localization, cellular uptake, and RNAi in living cells. Chem Biol 2004; $11: 1165-75$.

[11] Eguchi A, Meade BR, Chang Y-C, Fredrickson CT, Willert K, Puri N, et al. Efficient siRNA delivery into primary cells by a peptide transduction domain-dsRNA binding domain fusion protein. Nat Biotechnol 2009;27:567-71.

[12] Choi Y-S, Lee JY, Suh JS, Kwon Y-M, Lee S-J, Chung J-K, et al. The systemic delivery of siRNAs by a cell penetrating peptide, low molecular weight protamine. Biomaterials 2010;31:1429-43.

[13] Anderson D, Nichols E, Manger R, Woodle D, Barry M, Fritzberg A. Tumor cell retention of antibody Fab fragments is enhanced by an attached HIV TAT protein-derived peptide. Biochem Biophys Res Commun 1993;194: 876-84.

[14] Hu M, Chen P, Wang J, Scollard DA, Vallis KA, Reilly RM. 123I-labeled HIV-1 tat peptide radioimmunoconjugates are imported into the nucleus of human breast cancer cells and functionally interact in vitro and in vivo with the cyclindependent kinase inhibitor, p21WAF-1/Cip-1. Eur J Nucl Med Mol Imaging 2007:34:368-77.

[15] Lewin M, Carlesso N, Tung C-H, Tang X-W, Cory D, Scadden DT, et al. Tat peptidederivatized magnetic nanoparticles allow in vivo tracking and recovery of progenitor cells. Nat Biotechnol 2000;18:410-4.

[16] Derfus AM, Chan WC, Bhatia SN. Intracellular delivery of quantum dots for live cell labeling and organelle tracking. Adv Mater 2004;16:961-6.

[17] Santra S, Yang H, Dutta D, Stanley JT, Holloway PH, Tan W, et al. TAT conjugated, FITC doped silica nanoparticles for bioimaging applications. Chem Commun 2004:2810-1.

[18] Zhang K, Fang H, Chen Z, Taylor J-SA, Wooley KL. Shape effects of nanoparticles conjugated with cell-penetrating peptides (HIV Tat PTD) on CHO cell uptake. Bioconjug Chem 2008:19:1880-7.

[19] Fittipaldi A, Ferrari A, Zoppé M, Arcangeli C, Pellegrini V, Beltram F, et al. Cell membrane lipid rafts mediate caveolar endocytosis of HIV-1 Tat fusion proteins. J Biol Chem 2003;278:34141-9.

[20] Richard JP, Melikov K, Vives E, Ramos C, Verbeure B, Gait MJ, et al. Cellpenetrating peptides A reevaluation of the mechanism of cellular uptake. J Biol Chem 2003;278:585-90.

[21] El-Andaloussi S, Johansson HJ, Lundberg P, Langel Ü. Induction of splice correction by cell-penetrating peptide nucleic acids. J Gene Med 2006;8: 1262-73.

[22] Nakase I, Niwa M, Takeuchi T, Sonomura K, Kawabata N, Koike Y, et al. Cellular uptake of arginine-rich peptides: roles for macropinocytosis and actin rearrangement. Mol Ther 2004;10:1011-22.

[23] Wadia JS, Stan RV, Dowdy SF. Transducible TAT-HA fusogenic peptide enhances escape of TAT-fusion proteins after lipid raft macropinocytosis. Nat Med $2004 ; 10: 310-5$

[24] Magzoub M, Sandgren S, Lundberg P, Oglęcka K, Lilja J, Wittrup A, et al. N-terminal peptides from unprocessed prion proteins enter cells by macropinocytosis. Biochem Biophys Res Commun 2006;348:379-85.

[25] Takeuchi T, Kosuge M, Tadokoro A, Sugiura Y, Nishi M, Kawata M, et al. Direct and rapid cytosolic delivery using cell-penetrating peptides mediated by pyrenebutyrate. ACS Chem Biol 2006;1:299-303.

[26] Liu BR, Huang Y-W, Winiarz JG, Chiang H-J, Lee H-J. Intracellular delivery of quantum dots mediated by a histidine-and arginine-rich HR9 cell-penetrating peptide through the direct membrane translocation mechanism. Biomaterials 2011;32:3520-37.

[27] Berlose JP, Convert O, Derossi D, Brunissen A, Chassaing G. Conformational and associative behaviours of the third helix of antennapedia homeodomain in membrane-mimetic environments. Eur J Biochem 1996:242:372-86.

[28] Derossi D, Calvet S, Trembleau A, Brunissen A, Chassaing G, Prochiantz A. Cell internalization of the third helix of the Antennapedia homeodomain is receptor-independent. J Biol Chem 1996:271:18188-93.

[29] Kawamoto S, Takasu M, Miyakawa T, Morikawa R, Oda T, Futaki S, et al. Inverted micelle formation of cell-penetrating peptide studied by coarse-grained simulation: importance of attractive force between cell-penetrating peptides and lipid head group. J Chem Phys 2011:134:095103.

[30] Frankel AD, Pabo CO. Cellular uptake of the tat protein from human immunodeficiency virus. Cell 1988;55:1189-93.

[31] Green M, Loewenstein PM. Autonomous functional domains of chemically synthesized human immunodeficiency virus tat trans-activator protein. Cell 1988;55:1179-88.
[32] Perez F, Joliot A, Bloch-Gallego E, Zahraoui A, Triller A, Prochiantz A. Antennapedia homeobox as a signal for the cellular internalization and nuclear addressing of a small exogenous peptide. J Cell Sci 1992;102:717-22.

[33] Derossi D, Joliot AH, Chassaing G, Prochiantz A. The third helix of the Antennapedia homeodomain translocates through biological membranes. J Biol Chem 1994;269:10444-50.

[34] Elliott G, O'Hare P. Intercellular trafficking and protein delivery by a herpesvirus structural protein. Cell 1997;88:223-33.

[35] Phelan A, Elliott G, O'Hare P. Intercellular delivery of functional p53 by the herpesvirus protein VP22. Nat Biotechnol 1998;16:440-3.

[36] Izumi S, Fujie J, Yamada S, Tomino S. Molecular properties and biosynthesis of major plasma proteins in Bombyx mori. Biochim Biophys Acta (BBA)-Protein Structure 1981;670:222-9.

[37] Mori S, Izumi S, Tomino S. Structures and organization of major plasma protein genes of the silkworm Bombyx mori. J Mol Biol 1991;218:7-12.

[38] Bosquet G, Guillet C, Calvez B, Chavancy G. The regulation of major haemolymph protein synthesis: changes in mRNA content during the development of Bombyx mori larvae. Insect Biochem 1989;19:29-39.

[39] Mori S, Izumi S, Tomino S. Complete nucleotide sequences of major plasma protein genes of Bombyx mori. Biochim Biophys Acta (BBA)-Gene Structure and Expression 1991;1090:129-32.

[40] Mine E, Izumi S, Katsuki M, Tomino S. Developmental and sex-dependent regulation of storage protein synthesis in the silkworm, Bombyx mori. Dev Biol 1983;97:329-37

[41] Zhong BX, Li JK, Lin JR, Liang JS, Su SK, Xu HS, et al. Possible effect of 30K proteins in embryonic development of silkworm Bombyx mori. Acta Biochim Biophys Sin 2005;37:355-61

[42] Ogawa N, Kishimoto A, Asano T, Izumi S. The homeodomain protein PBX participates in JH-related suppressive regulation on the expression of major plasma protein genes in the silkworm, Bombyx mori. Insect Biochem Mol Biol 2005;35:217-29

[43] Rhee WJ, Kim EJ, Park TH. Kinetic effect of silkworm hemolymph on the delayed host cell death in an insect cell-baculovirus system. Biotechnol Prog 1999; 15:1028-32.

[44] Rhee WJ, Park TH. Silkworm hemolymph inhibits baculovirus-induced insect cell apoptosis. Biochem Biophys Res Commun 2000;271:186-90.

[45] Kim EJ, Rhee WJ, Park TH. Isolation and characterization of an apoptosisinhibiting component from the hemolymph of Bombyx mori. Biochem Biophys Res Commun 2001:285:224-8.

[46] Choi SS, Rhee WJ, Park TH. Inhibition of human cell apoptosis by silkworm hemolymph. Biotechnol Prog 2002;18:874-8.

[47] Rhee WJ, Kim EJ, Park TH. Silkworm hemolymph as a potent inhibitor of apoptosis in Sf9 cells. Biochem Biophys Res Commun 2002;295:779-83.

[48] Kim EJ, Park HJ, Park TH. Inhibition of apoptosis by recombinant 30K protein originating from silkworm hemolymph. Biochem Biophys Res Commun 2003;308:523-8

[49] Kim EJ, Park TH. Anti-apoptosis engineering. Biotechnol Bioprocess Eng $2003 ; 8: 76-82$

[50] Park HJ, Kim EJ, Koo TY, Park TH. Purification of recombinant 30K protein produced in Escherichia coli and its anti-apoptotic effect in mammalian and insect cell systems. Enzyme Microb Technol 2003;33:466-71.

[51] Kim EJ, Rhee WJ, Park TH. Inhibition of apoptosis by a Bombyx mori gene. Biotechnol Prog 2004;20:324-9.

[52] Choi SS, Rhee WJ, Kim EJ, Park TH. Enhancement of recombinant protein production in Chinese hamster ovary cells through anti-apoptosis engineering using 30Kc6 gene. Biotechnol Bioeng 2006;95:459-67.

[53] Park JH, Park HH, Park TH. Cellular engineering for the high-level production of recombinant proteins in mammalian cell systems. Korean J Chem Eng 2010;27:1042-8

[54] Wang Z, Ma X, Fan L, Rhee WJ, Park TH, Zhao L, et al. Understanding the mechanistic roles of $30 \mathrm{Kc} 6$ gene in apoptosis and specific productivity in antibody-producing Chinese hamster ovary cells. Appl Microbiol Biotechnol 2012;94:1243-53

[55] Wang Z, Ma X, Zhao L, Fan L, Tan W-S. Expression of anti-apoptotic 30Kc6 gene inhibiting hyperosmotic pressure-induced apoptosis in antibody-producing Chinese hamster ovary cells. Process Biochem 2012;47:735-41.

[56] Ha SH, Park TH, Kim S-E. Silkworm hemolymph as a substitute for fetal bovine serum in insect cell culture. Biotechnol Tech 1996;10:401-6.

[57] Ha S, Park T. Efficient production of recombinant protein in Spodoptera frugiperda/AcNPV system utilizing silkworm hemolymph. Biotechnol Lett 1997:19:1087-91.

[58] Choi SS, Park TH. Enhancement of sialyltransferase-catalyzed transfer of sialic acid onto glycoprotein oligosaccharides using silkworm hemolymph and its 30K protein. J Mol Catal B: Enzym 2006:43:128-32.

[59] Koo TY, Park JH, Park HH, Park TH. Beneficial effect of 30Kc6 gene expression on production of recombinant interferon- $\beta$ in serum-free suspension culture of CHO cells. Process Biochem 2009;44:146-53.

[60] Wang Z, Park JH, Park HH, Tan W, Park TH. Enhancement of therapeutic monoclonal antibody production in CHO cells using 30Kc6 gene. Process Biochem 2010;45:1852-6

[61] Wang Z, Park JH, Park $\mathrm{HH}$, Tan W, Park TH, Enhancement of recombinant human EPO production and sialylation in Chinese hamster ovary cells through Bombyx mori 30Kc19 gene expression. Biotechnol Bioeng 2011;108: 1634-42.

[62] Park JH, Park HH, Choi SS, Park TH. Stabilization of enzymes by the recombinant 30Kc19 protein. Process Biochem 2012;47:164-9. 
[63] Choi SS, Rhee WJ, Park TH. Beneficial effect of silkworm hemolymph on a CHO cell system: inhibition of apoptosis and increase of EPO production. Biotechnol Bioeng 2005;91:793-800.

[64] Yang J-P, Ma X-X, He Y-X, Li W-F, Kang Y, Bao R, et al. Crystal structure of the 30K protein from the silkworm Bombyx mori reveals a new member of the $\beta$-trefoil superfamily. J Struct Biol 2011;175:97-103.

[65] Pietrzyk AJ, Panjikar S, Bujacz A, Mueller-Dieckmann J, Lochynska M, Jaskolski M, et al. High-resolution structure of Bombyx mori lipoprotein 7: crystallographic determination of the identity of the protein and its potential role in detoxification. Acta Crystallogr Sect D: Biol Crystallogr 2012;68:1140-51.

[66] Pietrzyk AJ, Panjikar S, Bujacz A, Mueller-Dieckmann J, Lochynska M, Jaskolski M, et al. High-resolution structure of Bombyx mori lipoprotein 7: crystallographic determination of the identity of the protein and its potential role in detoxification. Acta Crystallogr Sect D: Biol Crystallogr 2012;68:1140-51.

[67] Park JH, Lee JH, Park HH, Rhee WJ, Choi SS, Park TH. A protein delivery system using 30Kc19 cell-penetrating protein originating from silkworm. Biomaterials 2012;33:9127-34.

[68] Chen J, Li G, Lu J, Chen L, Huang Y, Wu H, et al. A novel type of PTD, common helix-loop-helix motif, could efficiently mediate protein transduction into mammalian cells. Biochem Biophys Res Commun 2006;347:931-40.

[69] Morris MC, Deshayes S, Heitz F, Divita G. Cell-penetrating peptides: from molecular mechanisms to therapeutics. Biol Cell 2008;100:201-17.

[70] Åmand HL, Nordén B, Fant K. Functionalization with C-terminal cysteine enhances transfection efficiency of cell-penetrating peptides through dimer formation. Biochem Biophys Res Commun 2012:418:469-74.

[71] Kaplan IM, Wadia JS, Dowdy SF. Cationic TAT peptide transduction domain enters cells by macropinocytosis. J Control Release 2005;102:247-53.

[72] Gump JM, Dowdy SF. TAT transduction: the molecular mechanism and therapeutic prospects. Trends Mol Med 2007;13:443-8.

[73] Lundberg M, Wikström S, Johansson M. Cell surface adherence and endocytosis of protein transduction domains. Mol Ther 2003;8:143-50.

[74] Tünnemann G, Martin RM, Haupt S, Patsch C, Edenhofer F, Cardoso MC. Cargodependent mode of uptake and bioavailability of TAT-containing proteins and peptides in living cells. FASEB J 2006;20:1775-84.

[75] Schwarze SR, Ho A, Vocero-Akbani A, Dowdy SF. In vivo protein transduction: delivery of a biologically active protein into the mouse. Science 1999;285:1569-72.
[76] Cai S-R, Xu G, Becker-Hapak M, Ma M, Dowdy SF, McLeod HL. The kinetics and tissue distribution of protein transduction in mice. Eur J Pharm Sci 2006;27:311-9.

[77] Choi J-M, Ahn M-H, Chae W-J, Jung Y-G, Park J-C, Song H-M, et al Intranasal delivery of the cytoplasmic domain of CTLA-4 using a novel protein transduction domain prevents allergic inflammation. Nat Med 2006;12 574-9.

[78] Borstad GC, Bryant LR, Abel MP, Scroggie DA, Harris MD, Alloway JA. Colchicine for prophylaxis of acute flares when initiating allopurinol for chronic gouty arthritis. J Rheumatol 2004;31:2429-32.

[79] Lee CK, Son SH, Park KK, Park JHY, Lim SS, Kim SH, et al. Licochalcone A inhibits the growth of colon carcinoma and attenuates cisplatin-induced toxicity without a loss of chemotherapeutic efficacy in mice. Basic Clin Pharmacol Toxicol 2008; $103: 48-54$

[80] Vives E, Brodin P, Lebleu B. A truncated HIV-1 Tat protein basic domain rapidly translocates through the plasma membrane and accumulates in the cell nucleus. J Biol Chem 1997;272:16010-7.

[81] Torchilin VP, Levchenko TS, Rammohan R, Volodina N, PapahadjopoulosSternberg B, D'Souza GG. Cell transfection in vitro and in vivo with nontoxic TAT peptide-liposome-DNA complexes. Proc Natl Acad Sci 2003;100:1972-7.

[82] Sugita T, Yoshikawa T, Mukai Y Yamanada N, Imai S, Nagano K, et al. Comparative study on transduction and toxicity of protein transduction domains. $\mathrm{Br}$ J Pharmacol 2008;153:1143-52.

[83] Akkarawongsa R, Cullinan AE, Zinkel A, Clarin J, Brandt CR. Corneal toxicity of cell-penetrating peptides that inhibit herpes simplex virus entry. J Ocul Pharmacol Ther 2006;22:279-89.

[84] Johansson HJ, El-Andaloussi S, Holm T, Mäe M, Jänes J, Maimets T, et al. Characterization of a novel cytotoxic cell-penetrating peptide derived from p14ARF protein. Mol Ther 2008;16:115-23.

[85] Ignatovich IA, Dizhe EB, Pavlotskaya AV, Akifiev BN, Burov SV, Orlov SV, et al Complexes of plasmid DNA with basic domain 47-57 of the HIV-1 Tat protein are transferred to mammalian cells by endocytosis-mediated pathways. J Biol Chem 2003;278:42625-36.

[86] Meade AJ, Meloni BP, Mastaglia FL, Knuckey NW. The application of cell penetrating peptides for the delivery of neuroprotective peptides/proteins in experimental cerebral ischaemia studies. J Exp Stroke Translational Med 2009;2:22-40. 